\title{
プラスチックス床材の弾力性・硬度の変化について
}

正会員剤藤

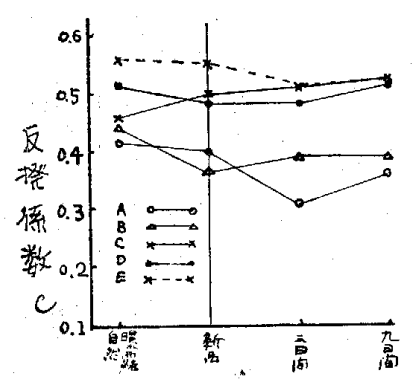

第 1 図 淡緑色グループ

$\S$ 試験結果 の測定は 25 ${ }^{\circ} \mathrm{C} \pm 1^{\circ} \mathrm{C}$ の恒温室内にて 行った。

\section{3. 実験結果について}

各試料の色相によって紫 外線の吸収率が異なり、そ れぞれ特有の変化状態をな すと仮定して実験結果を第

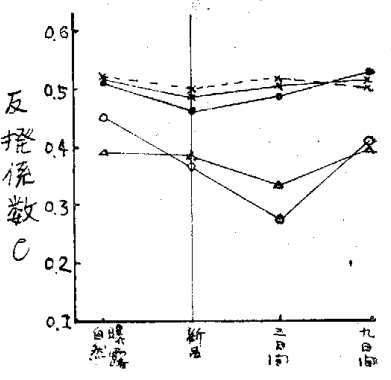

第 2 図 淡綢色グループ

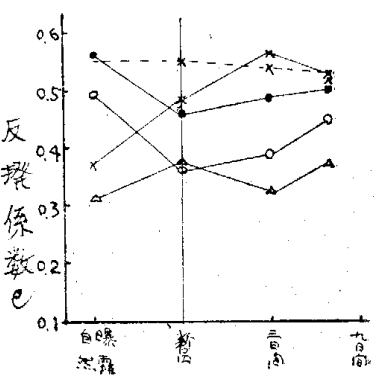

第 3 図灰色グループ す反撥係数 $e$ の求め方は東北大吉岡氏 ${ }^{1)}$ の御提案せるる のによった。

\section{2. 実験方法}

§試 料
記号 A
” B …硬質塩化ビニール樹脂
" C ...半硬質塩化ビニール樹脂
" D …軟質塩化ビニール樹脂
" E $\mathrm{E}$ …硬質塩化ビニール樹脂

各種とも淡緑、淡茶、灰の三色、各色 3 ケの半均値を とった。武料の大きさは $5 \times 15 \mathrm{~m}$ である。

\section{$\S$ 自然曝露}

大阪市西区所在鉄筋コンクリート3 階建の屋上にて高 $さ 1.8 \mathrm{~m}$ の木枠に水平に静置した。期間は昭和 37 年 6 月 25 日〜同年 10 月 25 日の 4 ケ月間

\section{$\S$ 人工促進曝露}

太陽理化器 $\mathrm{KK}$ 製全自動祀色度試験機を使用した。本 機はカーボンアーク 1 灯掛、シャワーなし。機内温度 $50^{\circ} \mathrm{C}$ である。

* 大阪市立大学講師
$1 \sim 3$ 図のごとく示した（硬度は省略）

自然曝露 4 ケ月はこの種の実験としては短いが、もと もと床材は外壁材、その他之亏がって直接日光の紫外線 に曝されることはなく大部分は反射によるものである。 したがって夏期日射の強い 4 ケ月でも相当卡の傾向を知 ることが出来ると考える。

歩行に関係する弾力性は反撥係数によって判断し、反 撥係数が小さいときは衝撃吸収率 $\left(1-e^{2}\right)$ は大きく、歩 行により大きな力がいる。普通歩きにくくなる。

最初プラスチック床材を紫外線で照射すると所謂老化 現象を来たして弾力性を失ひ反撥係数が小さくなるるの と仮定したが、色相による差異忹余りなく各材種とも自 然儤露、九日間促進曝露では若干大きくなっている。

しかし各材種とす厚さは 2 3.2 mm で大変薄いから 実際の歩行時には下地の状態が大きく影響するものと考 えられる。

註 1）吉岡 丹：“各種床材料の弾力性測定装置の試作” 日 本建築学会論文集第 63 号 